\title{
Pengaruh Tax Avoidance Terhadap Cost Of Debt Pada Perusahaan Manufaktur Yang Terdaftar Di Bursa Efek Indonesia
}

\author{
F. Anto Manullang ${ }^{1}$, Hendra Agustinus H. Marbun, S.E., M.Si., Ak, CA ${ }^{2}$, Irene M Tarigan, SE. Ak, \\ M.Ak, CA, BKP, CPA ${ }^{3}$, Binsar Sihombing, S.E., M.Si. ${ }^{4}$ \\ Politeknik Wilmar Bisnis Indonesi

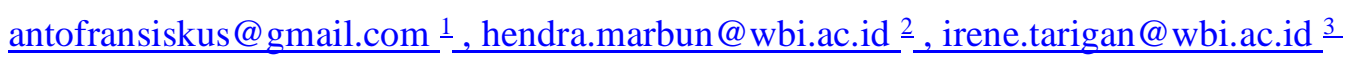 \\ binsar.sihombing@wbi.ac.id ${ }^{4}$
}

\begin{abstract}
ABSTRAK
Tax avoidance merupakan upaya yang dilakuakan untuk pajak tanpa melanggar ketentuan perpajakan itu sendiri, Berbeda dengan tax evasion, yang merupakan kecurangan pajak dengan melanggar ketentuan-ketentuan pajak yang berlaku. Penelitian ini bertujuan untuk menguji pengaruh variabel Penghindaran Pajak (Tax Avoidance) terhadap Biaya Utang.

Sampel dalam penelitian ini berjumlah 46 perusahaan manufaktur yang terdaftar di Bursa Efek Indonesia. Data yang digunakan adalah data sekunder dari setiap perusahaan laporan tahunan perusahaan manufaktur yang terdaftar di Bursa Efek Indonesia selama 3 tahun yaitu dari tahun 2015 sampai 2017. Pengambilan sampel dengan menggunakan teknik purposive sampling. Analisis data menggunakan analisis regresi linear berganda dengan menggunakan program spss. Pengujian hipotesis yang dilakukan dengan Uji Koefisien Determinasi,Uji F, dan Uji t.

Hasil penelitian menunjukkan bahwa variabel Tax Avoidance tidak berpengaruh terhadap Cost Of Debt dan variabel kontrol Ukuran Perusahaan tidak berpengaruh terhadap biaya hutang, dan Return On Assets berpengaruh negatif dan signifikan terhadap Cost Of Debt pada perusahaan manufaktur yang terdaftar di Bursa Efek Indonesia.

Tax avoidance tidak berpengaruh terhadap cots of debt. Dalam penelitian ini dapat diketahui bahwa tax avoidance tidak dapat mempengaruhi cost of debt secra tersendiri, tax avoidance berpengaruh ketika size dan return on asset sebaagai variabel kontrol yang memperkuat pengaruh tax avoidance terhadap cots of debt. Periode penelitian ini juga dilakukan setelah pemerintah melakukan reformasi perpajakan dan juga dengan adanya Peraturan Menteri Keuangan No.169/PMK.010/2015 mengenai besaran perbandingan hutang dan modal perusahaan yang telah dikeluarkan pada tahun 2015 yang membuat perusahaan pada saat ini berhati-hati di dalam mengelola hutang.
\end{abstract}

Kata kunci :Tax avoidance, Cost of debt, Perusahaan Manufaktur 


\begin{abstract}
Tax avoidance is an attempt made to tax without violating the tax provisions themselves, In contrast to tax evasion, which is a tax fraud by violating the applicable tax provisions. This study aims to examine the effect of the variable Tax Avoidance on the Cost of Money.

The sample in this study amounted to 46 manufacturing companies listed on the Indonesia Stock Exchange. The data used are secondary data from each company annual reports of manufacturing companies listed on the Indonesia Stock Exchange for 3 years, namely from 2015 to 2017. Sampling using a purposive sampling technique. Data analysis using multiple linear regression analysis using the SPSS program. Hypothesis testing is done by the Coefficient of Determination Test, F Test, and t Test.

The results showed that the Tax Avoidance variable did not affect the Cost of Debt and the control variable Company Size did not affect the cost of debt, and Return On Assets had a negative and significant effect on the Cost of Debt on manufacturing companies listed on the Indonesia Stock Exchange.

Tax avoidance has no effect on cots of debt. In this study it can be seen that tax avoidance cannot affect the cost of debt separately, tax avoidance influences when the size and return on assets as control variables that strengthen the effect of tax avoidance on cots of debt. This research period was also conducted after the government carried out tax reforms and also with the Minister of Finance Regulation No.169 / PMK.010 / 2015 regarding the magnitude

of the ratio of debt and capital of the company that was issued in 2015 which makes the company cautious at this time in managing debt.
\end{abstract}

Keywords: Tax avoidance, Cost of debt, Size, manufacturing companies 


\section{Pendahuluan}

\subsection{Latar Belakang}

Perkembangan bisnis di dunia telah memberi pengaruh besar, khususnya di Indonesia yang saat ini telah memasuki era globalisasi. Perkembangan dunia usaha ini menyebabkan persaingan yang semakin tajam, sehingga perusahaan harus mampu mempertahankan kelangsungan operasional perusahaan sekaligus berkembang sesuai dengan visi, misi dan tujuan perusahaan. Perkembangan ini jugalah yang menyebabkan perusahaan akan melakukan berbagai strategi dan usaha untuk memenangkan persaingan antara perusahaan agar berjalan sesuai dengan tujuannya.

Dalam rangka mempertahankan dan mengembangkan bisnisnya perusahaan membutuhkan sumber pendanaan eksternal. Salah satu pendanaan eksternal yang dilakukan yaitu, dengan menerbitkan surat hutang yang akan dibeli oleh kreditur. Dengan membeli surat hutang, kreditur akan memdapatkan return berupa bunga. Perusahaan yang berutang akan memberikan bunga sebagai pengembalian yang harus diberikan perusahaan kepada kreditur. Situmeang (2017) mengatakan tingkat pengembalian yang diberikan perusahaan inilah yang akan menjadi cost of debt (biaya hutang) bagi perusahaan.

Kreditur selaku pihak eksternal, sebelum meminjamkan dana harus memperhatikan atau mempertimbangkan resiko-resiko yang akan dihadapi. Maka dari itu, selaku kreditur harus mengetahui tinggi rendahnya resiko dari kondisi pasar perusahaan tersebut (Nugrahadi, 2020). Dari tingginya risiko ini perusahaan akan di bebankan biaya hutang yang tinggi. Biaya hutang inilah yang menjadi return bagi kreditor atas investasi yang di berikan terhadap perusahaan dan perusahan akan mencatatnya sebagai hutang atas pinjaman modal / investasi.

Hutang merupakan suatu mekanisme lain yang bisa digunakan untuk mengurangi atau mengontrol konflik keagenan. Dengan hutang, maka perusahaan harus melakukan pembayaran periodik atas bunga dan prinsipal. Hal ini bisa mengurangi keinginan manajer untuk menggunakan free cash flow guna membiayai kegiatan-kegiatan yang tidak optimal. Penggunaan hutang juga akan meningkatkan risiko, oleh karena itu manajer akan lebih berhati-hati karena risiko hutang lebih besar dari pada investor publik. Dengan kata lain, perusahaan yang menggunakan hutang dalam pendanaannya dan tidak mampu melunasi kembali hutang tersebut akan terancam likuiditasnya sehingga pada gilirannnya akan mengancam posisi manajemen. Disisi lain perusahaan diuntungkan oleh adanya biaya hutang tersebut, dimana perusahaan dapat menghemat pajak perusahaan dan mengurangi beban pajak yang harus dibayar perusahaan.

Upaya dalam penghematan pajak dapat dilakukan dengan beberapa cara, baik dengan melakukan tax avoidance (penghindaran pajak) atau pun dengan melakukan kecurangan pajak (tax evasion). Penghindaran pajak (tax avoidance) harus dibedakan dari penggelapan pajak (tax evasion), karena penggelapan pajak berkaitan dengan tindakan yang melanggar hukum (illegal) untuk mengurangi atau bahkan menghilangkan beban pajak, sedangkan penghindaran pajak dilakukan secara legal, yaitu dengan memanfaatkan kesempatan yang ada untuk menghindari pembayaran pajak atau melakukan transaksi yang digunakan untuk menghindari pajak. Menurut Dyreng et al. (2008) dalam Indah Masri (2012), tax avoidance merupakan segala bentuk kegiatan yang bentuk kegiatan yang memberikan pengaruh terhadap kewajiban pajak, baik kegiatan yang diperbolehkan oleh pajak atau kegiatan khusus untuk mengurangi pajak.

Berdasarkan uraian dan latar belakang di atas, maka penulis melakukan penelitian dengan menggunakan judul : "Pengaruh Tax Avoidance Terhadap Cost of Debt"

\subsection{Rumusan Masalah}

Berdasarkan latar belakang penelitian di atas, rumusan masalah yang dapat diidentifikasikan oleh penulis sebagai berikut: "Apakah tax avoidance (penghindaran pajak) berpengaruh posistif terhadap cots of debt (biaya hutang) pada perusahaan manufaktur yang terdaftar di Bursa Efek Indonesia?" 


\subsection{Tujuan Penelitian}

Berdasarkan rumusan masalah di atas, maka tujuan dari penelitian ini, yaitu : "Untuk mengetahui apakah penghindaran pajak berpengaruh positif terhadap biaya hutang pada perusahaan manufaktur yang terdaftar di Bursa Efek Indonesia ?"

\subsection{Manfaat Penelitian}

Berdasarkan tujuan penelitian tersebut, maka hasil penelitian ini diharapkan penulis dapat memberikan manfaat sebagai berikut :

1. Manfaat Teoritis

Hasil dari penelitian ini diharapkan dapat memberikan pengembangan ilmu ekonomi, khususnya pada bidang ilmu perpajakan, akuntansi keuangan dan manajemen keuangan.

Hasil penelitian ini juga diharapkan dapat menjadi bahan referensi dan perbandingan untuk penelitian-penelitian selanjutnya yang berkaitan dengan penghindaran pajak dan biaya utang.

2. Manfaat Bagi Praktisi

a. Bagi Perusahaan

Penelitian ini diharapkan dapat memberikan motivasi bagi perusahaan untuk menyajikan laporan tahunan yang lebih transparan dan dan dapat diandalkan. Karena melalui laporan yang disajikan oleh perusahaan dapat menjadi pertimbangan bagi investor untuk menginvestasikan dananya.

b. Bagi Pemerintah

Penelitian ini diharapkan dapat menjadi evaluasi bagi pemerintah mengenai praktik- praktik penghindaran pajak perusahaan. Sehingga diharapkan pemerintah dapat menentukan kebijakan yang tepat dalam menghadapi praktik penghindaran pajak.

c. Bagi Akademisi dan Peneliti

Penelitian ini diharapkan dapat menambah literatur mengenai praktik penghindaran pajak dan mendukung penelitian yang pernah dilakukan sebelumnya. Selain itu, diharapkan penelitian ini dapat memberikan informasi bagi penelitian yang akan dilakukan dalam penelitian berikutnya.

d. Bagi Investor

Penelitian ini diharapkan dapat memberikan masukan kepada calon investor mengenai seberapa besar risiko yang akan dihadapi investor dengan adanya penghindaran pajak terhadap biaya utang, sebagai pertimbangan untuk menanamkan modal.

\section{Tinjauan Pustaka}

\subsection{Trade Off Theory}

Trade off theory pertama kali diperkenalkan pada tahun 1963 oleh Modigliani dan Miller, teori ini menjelaskan bahwa berapa banyak utang perusahaan dan berapa banyak ekuitas perusahaan, sehingga terjadinya keseimbangan antara biaya dan keuntungan. Trade off theory berasumsi bahwa adanya manfaat pajak akibat penggunaan utang, sehingga perusahaan akan menggunakan utang sampai tingkat tertentu untuk memaksimalkan nilai perusahaan. Esensi trade off theory dalam struktur modal adalah menyeimbangkan manfaat dan pengorbanan yang timbul sebagai akibat penggunaan utang. Sejauh manfaat lebih besar, tambahan utang masih diperkenankan. Apabila pengorbanan karena penggunaan utang sudah lebih besar, maka tambahan utang sudah tidak diperbolehkan.

Trade off theory juga menjelaskan bahwa struktur modal yang optimal didasarkan atas keseimbangan antara manfaat dan biaya dari pembiayaan dengan pinjaman. Manfaat terbesar dari suatu pembiayaan dengan pinjaman adalah pengurangan pajak yang diperoleh atas bunga pinjaman, yang dapat mengurangi dalam menghitung pendapatan kena pajak.

\subsection{Cost of Debt (Biaya Hutang)}

Dalam rangka mempertahankan dan mengembangkan bisnisnya, perusahaan juga membutuhkan 
sumber pendanaan eksternal dari kreditur dalam bentuk utang. Return bagi kreditur ialah bunga yang dianggap perusahaan sebagai biaya hutang. Bagi perusahaan yang berutang, bunga merupakan pengembalian yang harus diberikan perusahaan pada kreditur sampai utang tersebut dapat dilunasi. Tingkat pengembalian inilah yang akan menjadi cost of debt bagi perusahaan (Marcelliana, 2014). Menurut Pittman dan Fortin ( dalam Masri dan Martani, 2012), Cost of debt diukur dengan membagi beban bunga yang dibayarkan oleh perusahaan dalam periode satu tahun dibagi dengan jumlah ratarata pinjaman jangka panjang dan pendek yang berbunga selama tahun tersebut.

Biaya utang setiap perusahaan dipengaruhi oleh berbagai faktor, seperti karakteristik perusahaan, biaya agensi, dan risiko untuk obligasi, dan masalah asimetri informasi, tingkat suku bunga, leverage dan arus kas dari operasi, dan ukuran perusahaan. Tempat penampungan pajak berfungsi sebagai pengganti pemotongan bunga dalam menentukan struktur modal dan biaya.

Penggunaan utang pada umumnya didasarkan pada pertimbangan biaya. Pada awalnya Modigliani dan Miller (1958) (Novianti 2014) mengemukakan bahwa pendanaan dengan utang dan ekuitas tidak mempengaruhi nilai perusahaan dengan asumsi tidak ada pajak, Asumsi ini dianggap tidak realistis, kemudian Modigliani dan Miler (1963) melakukan koreksi dengan memasukkan faktor pajak kedalam teorinya. Biaya bunga menjadi pengurang penghasilan sehingga dapat digunakan untuk menghemat pajak. Akibatnya semakin tinggi proporsi pendanaan dengan utang akan meningkatkan nilai perusahaan. Teori Modigliani dan Miller (1963) (dalam Novianti (2014) mengabaikan biaya kebangkrutan, implikasi dari teori tersebut adalah perusahaan menggunakan utang sebanyak-banyaknya, sedangkan penggunaan utang akan meningkatkan potensi kemungkinan perusahaan mengalami kebangkrutan. Tax shield dan potensi financial distress mendasari trade off theory, yaitu perusahaan akan berutang sampai pada titik optimal. Titik optimal ak an tercapai pada saat manfaat pajak dari utang (debt tax shields) sama dengan biaya akibat potensi kesulitan keuangan (financial distress).

\subsection{Return dan Risiko}

Investasi adalah merupakan suatu kebijakan untuk penanaman modal yang dimasukkan ke aktiva produktif selama waktu tertentu untuk memperoleh manfaat yang lebih tinggi. Ketika menginvestasikan dananya pada suatu atau beberapa aset, investor mengharapkan sejumlah return tertentu yang disebut dengan expected return yang dalam kenyataannya tidak selalu sama dengan return yang terealisasikan. Menurut Hartono (2014) dan Sihombing (2020), penyimpangan dari outcome yang diterima dengan ekspektasinya ini disebut risiko. Terdapat dua jenis risiko, yaitu risiko sistematis yang terkait dengan pasar modal tempat suatu sekuritas diperjual-belikan dan risiko perusahaan yang terkait dengan perusahaan yang menerbitkan suatu sekuritas. Return dan risiko merupakan dua hal yang tidak terpisahkan, karena pertimbangan suatu investasi merupakan tradeoff dari kedua faktor ini (Hartono, 2014). Return dan risiko ini memiliki hubungan yang positif.

\subsection{Pajak}

Pajak merupakan pendapatan suatu negara yang memiliki kontribusi yang tinggi dalam penerimaan pendapatan negara. Menurut Soemitro dalam Suandy (2011) mendefinisikan pajak sebagai iuran rakyat kepada kas negara yang berdasarkan undang- undang (yang dapat dipaksakan) dengan tidak mendapat jasa imbal (kontraprestasi), yang langsung dapat ditunjukkan dan yang digunakan untuk membayar pengeluaran umum. Salah satu jenis pajak adalah Pajak Penghasilan (PPh). Subjek PPh meliputi orang pribadi, warisan yang belum terbagi sebagai satu kesatuan, badan, dan bentuk usaha tetap.

\subsection{Tax Avoidance ( Penghindaran Pajak)}

Tax avoidance adalah upaya mengefisiensikan beban pajak dengan cara menghindari pengenaan pajak dengan mengarahkannya pada transaksi yang bukan objek pajak. Tax avoidance merupakan sebagai penghematan pajak yang timbul dengan memanfaatkan ketentuan perpajakan yang dilakukan secara legal untuk meminimalkan kewajiban pajak ( Lim 2011 dalam indah masri). Tax avoidance merupakan bagian dari tax planning yang dilakukan dengan tujuan meminimalkan pembayaran pajak. Tax avoidance secara hukum pajak tidak dilarang meskipun seringkali mendapat sorotan yang kurang baik dari kantor pajak karena dianggap memiliki konotasi yang negatif. Berbeda dengan tax evasion (penggelapan pajak), yang merupakan usaha-usaha memperkecil jumlah pajak dengan melanggar 
ketentuan-ketentuan pajak yang berlaku. Pelaku tax evasion dapat dikenakan sanksi administratif maupun sanksi pidana.

Menurut Brown salah satu definisi penghindaran pajak (tax avoidance) adalah "arrangement of a transaction in order to obtain a tax advantage, benefit, or reduction in a manner unintended by the tax law" ( Indah Masri 2012). Penggelapan pajak atau dikenal dengan istilah tax evasion yaitu penggelapan pajak terkait dengan penggunaan cara-cara yang melanggar hukum untuk mengurangi atau menghilangkan beban pajak sedangkan penghindaran pajak (tax avoidance) dilakukan secara "legal" dengan memanfaatkan kelemahan yang terdapat dalam peraturan perpajakan yang ada untuk menghindari pembayaran pajak atau melakukan transaksi yang tidak memiliki tujuan selain untuk menghindari pajak.

\subsection{Ukuran Perusahaan}

Ukuran perusahaan merupakan pengelompokkan perusahaan menjadi besar maupun perusahaan kecil yang didasarkan pada total aset perusahaan. Ukuran perusahaan dihitung dengan logaritma dari total aset. Semakin besar aset, penjualan, kapitalisasi pasar, maka ukuran perusahaan juga semakin besar. Aset merupakan nilai yang paling stabil sehingga digunakan sebagai acuan dalam penentuan ukuran perusahaan. Perusahaan yang besar akan membutuhkan dana yang besar pula yang digunakan sebagai sumber pendanaan, sehingga utang perusahaan juga akan menjadi besar (Masri dan Martani, 2012). Ukuran perusahaan dihitung dalam satuan nilai rupiah.

\subsection{Return On Assets}

Return On Asset (ROA) merupakan rasio yang digunakan untuk mengukur kemampuan perusahaan dalam menghasilkan laba yang berasal dari aktivitas investasi. Rasio ini digunakan untuk mengukur kemampuan manajemen dalam memperoleh keuntungan secara keseluruhan. Semakin besar ROA, semakin besar pula tingkat keuntungan yang dicapai oleh perusahaan tersebut dan semakin baik pula posisi perusahaan tersebut dari segi penggunaan aset. ROA dapat membantu perusahaan yang telah menjalankan praktik akuntansi dengan baik untuk dapat mengukur efisiensi penggunaan modal yang menyeluruh, yang sensitif terhadap setiap hal yang mempengaruhi keadaan keuangan perusahaan sehingga dapat diketahui posisi perusahaan terhadap industri (Situmeang, 2017). Hal ini merupakan salah satu langkah dalam perencanaan strategi. Laba merupakan tujuan utama yang ingin dicapai dalam sebuah usaha, termasuk juga bagi usaha perbankan. Alasan dari pencapaian laba perbankan tersebut dapat berupa kecukupan dalam memenuhi kewajiban terhadap pemegang saham, penilaian atas kinerja pimpinan, dan meningkatkan daya tarik investor untuk menanamkan modalnya.

\subsection{Peneltian Terdahulu}

Indah Masri dan Dwi Martani (2012) menganalisis pengaruh tax avoidance terhadap cots of debt, Hasil temuannya menunjukkan bahwa pengaruh tax avoidance terhadap cost of debt adalah positif dan kreditur memandang tax avoidance tersebut sebagai resiko sehingga perilaku tax avoidance justru meningkatkan cost of debt. Model penelitian dikembangkan dari model yang digunakan oleh Lim (2011) dengan menambahkan variabel pemoderasi struktur kepemilikan keluarga dan variabel kontrol growth dan DTA. Sedangkan variabel kontrol lainnya yaitu Age dan Size sesuai dengan penelitian $\operatorname{Lim}(2011)$.

Utkir Kholbadalov MSc (2012), melakukan analisis terhadap hubungan penghindaran pajak perusahaan, biaya utang dan kepemilikan institusional. Dalam penelitian ini, ditunjukkan bahwa penghindaran pajak berhubungan negatif terhadap hutang. Kerangka penelitian terdiri dari tujuh variable, variabel dependen adalah biaya utang, sementara penghindaran pajak perusahaan dan kepemilikan institusional adalah variabel independen, dan empat variabel kontrol, seperti umur perusahaan, leverage, ukuran perusahaan, dan arus kas dari operasi.

Sri Amanda Fitriani (2017) melakukan penelitian pengaruh penghindaran pajak (tax avoidance) terhadap biaya utang pada perusahaan manufaktur yang terdaftar di Bursa Efek Indonesia 2011-2015. Tax avoidance berpengaruh positif dan signifikan terhadap Biaya Utang (cost of debt) perusahaan manufaktur yang terdaftar di Bursa Efek Indonesia pada tahun 2011- 2015. Penelitian ini 
menggunakan 5 variabel yang terdiri dari tax avoidance, biaya utang, ukuran perusahaan, leverage, dan umur perusahaan.

Janice Ekasanti Santosa dan Heni Kurniawan (2016) melakukan analisis pengaruh tax avoidance terhadap cost of debt pada perusahaan manufaktur yang terdaftar di BEI periode 20102014. Berdasarkan analisis yang telah dilakukan, diperoleh hasil bahwa ETR (effective tax rate) sebagai proksi tax avoidance memiliki pengaruh negatif signifikan terhadap cost of debt sehingga dapat disimpulkan bahwa tax avoidance memiliki pengaruh positif signifikan terhadap cost of debt. Dalam penelitian ini ada dua variable yang di teliti, yaitu tax avoidance yang diukur dengan ETR sebagai variabel independen dan cost of debt sebagai variabel dependen.

\subsection{Pengembangan Hipotesis}

Trade off theory berasumsi bahwa adanya manfaat pajak akibat penggunaan utang, sehingga perusahaan akan menggunakan utang sampai tingkat tertentu untuk memaksimalkan nilai perusahaan. Trade of theory juga menjelaskan bahwa struktur modal yang optimal didasarkan atas keseimbangan antara manfaat dan biaya dari pembiayaan dengan pinjaman. Manfaat terbesar dari suatu pembiayaan dengan pinjaman adalah pengurangan pajak yang diperoleh atas bunga pinjaman, yang dapat mengurangi pendapatan dalam menghitung pendapatan kena pajak.

Perusahaan dalam membayar hutang sangat di pengaruhi penilaian kreditur, Dimana semakin besar risiko yang dimiliki suatu perusahaan maka beban bunga yang di bebakan kreditur terhadap perusahaan akan semakin besar. Bunga merupakan return bagi kreditur yang di tanggung oleh perusahaan yang dianggap perusahaan sebagai cost of debt. Ini berarti cost of debt yang ditanggung perusahaan dipengaruhi oleh penilaian kreditur mengenai risiko perusahaan.

Biaya hutang inilah yang dimanfaatkan pihak manajemen sebagai penghematan pajak atas beban pajak perusahaan yang disebut dengan tax avoidance. Dengan adanya tax avoidance sangat mempengaruhi nilai perusahaan dan transparansi laporan keuangan perusahaan. Sehingga pihak eksternal menilai tax avoidance sebagai tindakan yang berisiko sehingga membebankan bunga yang lebih tinggi, dapat disimpulkan bahwa semakin besar tingkat tax avoidance yang dilakukan oleh perusahaan maka akan semakin besar pula cost of debt yang ditanggung perusahaan.

Berdasarkan uraian tersebut, hipotesis penelitian ini dirumuskan sebagai berikut:

Hipotesis : Tax Avoidance berpengaruh positif terhadap cost of debt.

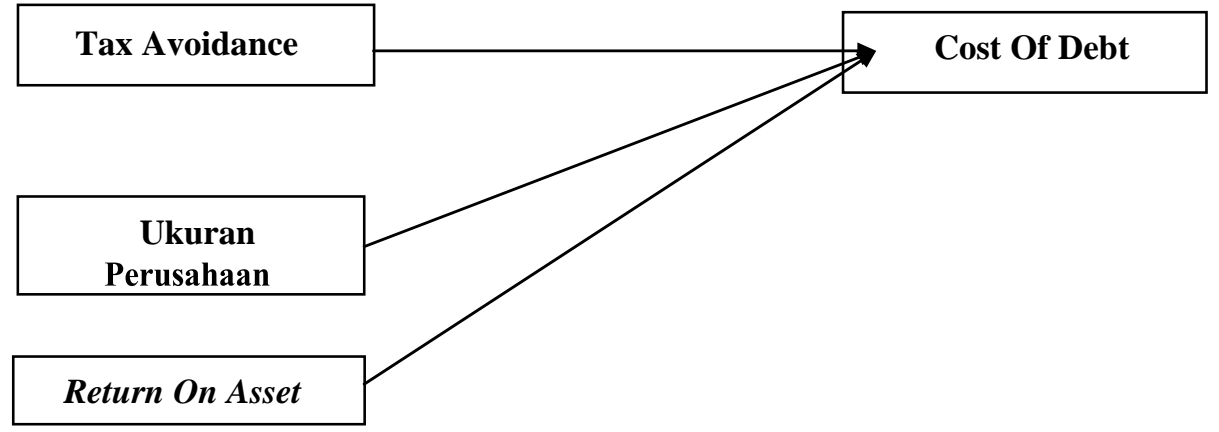

Gambar 2.1

Model penelitian

\section{Metode Penelitian}

\subsection{Populasi dan Sampel}

Populasi dalam penelitian ini adalah perusahaan manufaktur yang terdaftar di Bursa Efek Indonesia. Jenis penelitian ini adalah penelitian empiris dengan melakukan analisis pada perusahaan manufaktur yang terdaftar di BEI selama periode 2014-2017. Sampel dipilih menggunakan purposive sampling dengan kriteria:

1. Perusahaan manufaktur yang terdaftar di Bursa Efek Indonesia (BEI)

2. Perusahaan tidak listing dan delisting selama periode 2014-2017.

3. Perusahaan tidak melakukan kegiatan merger dan akuisisi, dan tidak melakukan perubahan 
terhadap kegiatan utamanya selama periode 2014-2017

4. Perusahaan yang memiliki beban bunga dan beban pajak kini

5. Perusahaan melaporkan keuangan yang diaudit.

6. Perusahaan mempublikasikan laporan keuangannya dengan menggunakan tahun buku keuangan yang dimulai pada 1 Januari sampai 31 Desember.

7. Perusahaan melaporkan laba yang positif

\subsection{Metodologi Penelitian}

Penelitian ini adalah penelitian kuantitatif demgan meneliti laporan perusahaan manufaktur tahun 2015 sampai 2017. Variabel dalam penelitian ini adalah Tax Avoidance, Cost of Debt, ukuran perusahaan, dan Return on Asset (ROA) yang dijelaskan secara rinci dalam tabel 3.1

Table 3.1

Operasionalisasi Variabel

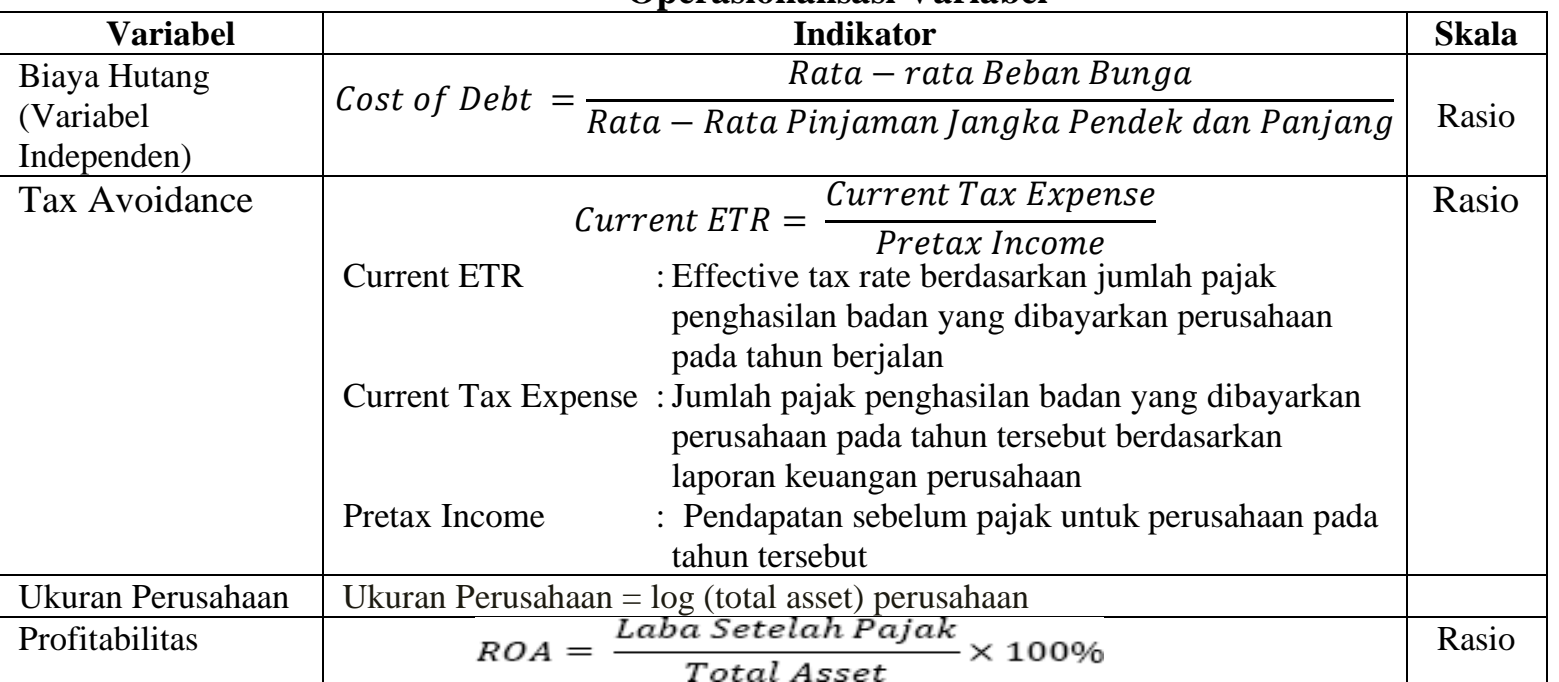

Teknik analisis data yang digunakan adalah analisis deskriptif dan regresi berganda. Pengujian prasyarat yang diperlukan seperti uji asumsi klasik dan pengujian lainnya dilakukan sebelum penerapan uji parametrik. Moderl yang akan diuji dalam penelitian ini adalah :

Model 1 : Pengaruh Current ETR terhadap COD ( tanpa variable kontrol)

$$
\mathrm{COD}_{\text {it }}=\alpha+\beta_{1} \text { Current } \text { ETR }_{\text {it }}+\varepsilon_{\text {it }}
$$

Model 2 : Pengaruh Current ETR dan COD (dengan adanya variable kontrol)

$$
\text { COD }_{i t}=\alpha+\beta_{1} \text { Current ETR }_{i t}+\beta_{2} \text { SIZE }_{i t}+\beta_{3} \text { ROA }_{i t}+\varepsilon i t
$$

\section{Hasil Dan Pembahasan}

\subsection{Deskripsi Objek Penelitian}

Pada bab ini akan dibahas hasil penelitian yang dilakukan setelah dilakukan tahap- tahap pengolahan data sehingga permasalahan dapat dianalisis. Dalam penelitian yang merupakan objek penelitian adalah perusahaan manufaktur yang terdaftar di Bursa Efek Indonesia selama periode 2015 - 2017. Objek penelitian terdiri dari 46 perusahaan manufaktur yang dipilih berdasarkan kriteria yang telah ditetapkan dengan menggunakan teknik purposive sampling. Tujuan penelitian ini adalah untuk mengetahui pengaruh penghindaran pajak (tax avoidance) terhadap biaya utang (cost of debt).

\subsection{Statistik Deskriptif}

Analisa statistik deskriptif digunakan untuk memberikan gambaran atas variabel- variabel yang digunakan dalam penelitian, tanpa membandingkan atau menghubungkan dengan variabel lain. Pengukuran yang digunakan dalam penelitian ini adalah mean, standar deviasi, nilai minimum, dan nilai maksimum dari masing-masing variabel yang digunakan dalam 
penelitian.

Tabel 4.1 Perhitungan Statistik Desk riptif

\begin{tabular}{|c|c|c|c|c|c|}
\hline \multicolumn{7}{|c|}{ Statistik Deskriptif } \\
\hline & $\mathrm{N}$ & Minimum & Maksimum & Mean & Standar Deviasi \\
\hline COD (cots of debt & 138 & 0.001 & 0.148 & 0.034 & 0.027 \\
\hline Tax Avoidance (ETR) & 138 & $(5.550)$ & 2.040 & 0.276 & 0.563 \\
\hline ROA (return on asset) & 138 & 0.0016 & 0.530 & 0.096 & 0.100 \\
\hline SIZE & 138 & 5.820 & 13.120 & 10.146 & 2.267 \\
\hline
\end{tabular}

a. Cost of Debt

Hasil statistik deskriptif menunjukkan bahwa nilai minimum cost of debt sebesar 0,001 pada PT. SMBR (Semen Baturaja Persero,Tbk) Pada tahun 2015 dan 2017, dan nilai maksimum sebesar 0.148 pada PT. UNIT (Nusantara Inti Corpora, Tbk) pada tahun 2015. Rata-rata cost of debt adalah sebesar 0,034 dengan standar deviasi sebesar 0,027 .

b. Tax Avoidance

Hasil statistik deskriptif menunjukkan bahwa nilai minimum tax avoidance sebesar - 5,550 pada PT. SRSN (Indo Acitama, Tbk) pada tahun 2016, dan nilai maximum sebesar 2,240 pada PT. TIRT (Tirta Mahakam Resources, Tbk) pada tahun 2015. Rata- rata Tax Avoidance adalah sebesar 0,276 dengan standar deviasi sebesar 0,563.

c. Return On Asset

Hasil statistik deskriptif menunjukkan bahwa nilai minimum return on asset sebesar 0,0016 pada PT. UNIT (Nusantara Inti Corpora, Tbk) pada tahun 2015 dan nilai maksimum sebesar 0,530 pada PT. MLBI (Multi Bintang Indonesia, Tbk) tahun 2017. Rata-rata return on asset adalah sebesar 0.096 dengan standar deviasi sebesar 0,100.

d. Ukuran Perusahaan (Size)

Hasil statistik deskriptif menunjukkan bahwa nilai minimum ukuran perusahaan (size) adalah sebesar 5,820 pada PT. ADES (Akasha Wira International Tbk) tahun 2015 dan nilai maksimum sebesar 13,120 pada PT. KLBF (Kalbe Farma Tbk) tahun 2017. Rata-rata ukuran perusahaan (size) adalah sebesar 10,146 dengan standar deviasi sebesar 2,267.

\subsection{Uji Asumsi Klasik}

Uji asumsi klasik yang dilakukan dalam penelitian ini terdiri dari uji multikolonieritas, uji autokorelasi, uji heteroskedastisitas, dan uji normalitas. Berikut adalah hasil dari uji asumsi klasik.

a. Uji Multikolonieritas

Uji multikolonieritas bertujuan untuk menguji apakah dalam model regresi ditemukan adanya korelasi antar variabel independen. Model regresi yang baik apabila di antara variabel independen tidak terjadi korelasi (Ghozali,2013). Pada penelitian ini, salah satu cara uji multikolonieritas dilakukan dengan menganalisis matrik korelasi antara variabel independen. Jika variabel independen memiliki korelasi di atas 0,90 maka model regresi terindikasi multikolonieritas. Hasil analisis dari matrik korelasi antar variabel independen akan ditunjukkan pada Tabel 4.2.

Tabel 4.2 Hasil Uji Multi Kolonieritas ( Matriks Kolerasi)

\begin{tabular}{|l|c|c|c|c|c|}
\hline \multirow{4}{*}{$\begin{array}{l}\text { Pearson } \\
\text { Correlation }\end{array}$} & & CoD & Tax_Avoid & ROA & Size \\
\cline { 2 - 6 } & CoD & 1.000 & .076 & -.302 & .026 \\
\cline { 2 - 6 } & Tax_Avoid & .076 & 1.000 & -.273 & .001 \\
\cline { 2 - 6 } & ROA & -.302 & -.273 & 1.000 & -.297 \\
\cline { 2 - 6 } & Size & .026 & .001 & -.297 & 1.000 \\
\hline \multirow{4}{*}{} & CoD &. & .188 & .000 & .382 \\
\cline { 2 - 6 } & Tax_Avoid & .188 &. & .001 & .494 \\
\hline
\end{tabular}




\begin{tabular}{|l|c|c|c|c|c|}
\cline { 2 - 6 } Sig. (1-tailed) & ROA & .000 & .001 &. & .000 \\
\cline { 2 - 6 } & Size & .382 & .494 & .000 &. \\
\hline
\end{tabular}

Berdasarkan tabel di atas, dapat kita lihat bahwa korelasi antar variabel independen berada di bawah 0,90. Sehingga, dapat dikatakan bahwa tidak ada multikolonieritas antar variabel independen. Langkah lain untuk mendeteksi adanya multikolonieritas dalam model regresi atau tidak yaitu melihat nilai tolerance dan variance inflation factor (VIF). Nilai yang menunjukkan adanya multikolonieritas dalam model regresi jika nilai tolerance $\leq 0,10$ dan nilai VIF $\geq 10$. Hasil uji multikolonieritas ini dapat dilihat pada tabel 4.3.

Tabel 4.3 Hasil Uji Multikolonieritas

\begin{tabular}{|c|c|c|c|c|c|}
\hline \multirow{2}{*}{ Model } & \multicolumn{2}{|c|}{ Correlations } & \multicolumn{2}{c|}{ Collinearity Statistics } \\
\cline { 2 - 6 } \multicolumn{2}{|c|}{1} & Partial & Part & Tolerance & VIF \\
\hline \multirow{3}{*}{1} & (Constant) & & & & \\
\cline { 2 - 6 } & Tax_Avoid & -.013 & -.013 & .919 & 1.088 \\
\cline { 2 - 6 } & ROA & -.300 & -.299 & .838 & 1.193 \\
\cline { 2 - 6 } & Size & -.071 & -.068 & .905 & 1.105 \\
\hline
\end{tabular}

Berdasarkan hasil uji multikolonieritas, dapat dilihat bahwa tidak ada variabel independen yang memiliki nilai toleransi kurang dari 0,10 . Hasil perhitungan nilai VIF juga menunjukkan tidak ada variabel independen yang memiliki nilai VIF lebih dari

10. Dengan demikian, dapat disimpulkan bahwa tidak ada multikolonieritas antar variabel independen dalam model regresi.

b. Uji Autokolerasi

Uji autokorelasi bertujuan untuk menguji apakah dalam model regresi linier ada korelasi antara kesalahan pengganggu pada periode $t$ dengan kesalahan pengganggu pada periode $t-$ 1 (sebelumnya). Jika terjadi kolerasi maka dinamakan ada problem autokorelasi. Model regresi yang baik adalah regresi yang bebas dari autokorelasi. Untuk menguji ada atau tidaknya autokorelasi antar model regresi, dapat dilakukan uji Durbin-Watson dengan syarat tidak ada variabel diantara variabel independen (Ghozali, 2013). Hasil uji autokorelasi dapat dilihat pada tabel 4.4.

Tabel 4.4 Hasil Uji Autokolerasi

\begin{tabular}{|c|c|c|c|}
\hline \multirow{2}{*}{ Model } & \multicolumn{2}{|c|}{ Change Statistics } & \multirow{2}{*}{ Durbin-Watson } \\
\cline { 2 - 3 } & df2 & Sig. F Change & \\
\hline 1 & $134^{\mathrm{a}}$ & .004 & 1.981 \\
\hline
\end{tabular}

Hasil uji Durbin - Watson menunjukkan nilai d sebesar 1,981. Nilai ini akan dibandingkan dengan tabel Durbin-Watson dengan nilai signifikansi 5\%, jumlah sampel 138 (n) dan jumlah variabel independen dan variabel kontrol $3(\mathrm{k}=3)$. Dari tabel di atas, dapat dilihat bahwa nilai d 1,981 berada dibatas atas (du) 1,7665 dan kurang dari 2,2335 (4- du), maka dapat disimpulkan bahwa dalam model regresi tidak ada autokorelasi positif atau negatif atau dapat disimpulkan tidak terdapat autokorelasi.

c. Uji Heteroskedastisitas

Uji heteroskedastisitas bertujuan menguji apakah dalam model regresi terjadi ketidaksamaan variance dari residual satu pengamatan ke pengamatan lain. Jika variance dari residual satu pengamatan ke pengamatan lain tetap disebut homoskedastisitas dan jika tidak tetap maka heteroskedastisitas (Ghozali, 2013). Model regresi yang baik adalah yang tidak terjadi heteroskedastisitas atau homoskedastisitas. Cara untuk melihat ada atau tidaknya heterokedastisitas adalah dengan melihat grafik plot antara nilai prediksi variabel terikat (ZPRED) dengan residualnya (SRESID). Jika tidak terdapat pola yang jelas, dan titik-titik menyebar di atas dan di bawah angka 0 pada sumbu Y, maka dalam model regresi tidak terjadi heteroskedastisitas. Hasil pengujian dapat dilihat pada Gambar 4.1. 


\section{Gambar 4.1. Hasil Uji Heteroskedastisitas}

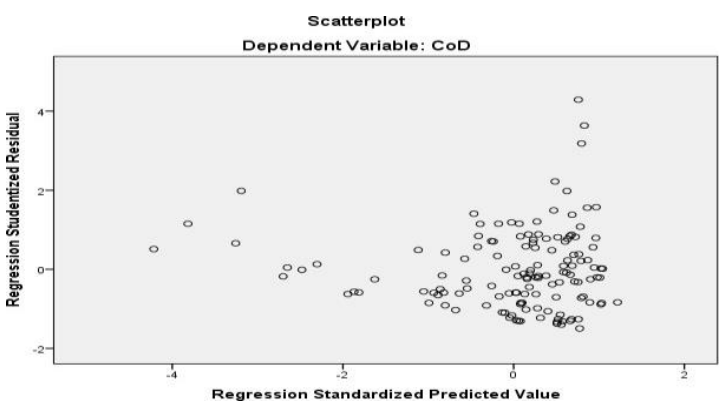

Berdasarkan gambar tersebut dapat dilihat bahwa titik-titik menyebar di atas dan di bawah angka 0 pada sumbu $Y$ dan tidak terdapat pola yang jelas. Jadi, dapat dikatakan bahwa model regresi dalam penelitian ini tidak terjadi heterokedastisitas dan layak untuk diuji.

\subsection{Uji Normalitas}

Uji normalitas bertujuan untuk menguji apakah dalam model regresi, variabel pengganggu atau residual memiliki distribusi normal atau tidak. Model regresi baik apabila mempunyai distribusi normal atau mendekati normal. Uji normalitas dalam penelitian ini menggunakan analisa grafik dan analisa statistik. Analisa grafik dalam penelitian ini dapat dilihat melalui normal probability plot. Hasil dari uji normalitas dengan normal probability plot ditunjukkan pada Gambar 4.2 dan Gambar 4.3 .
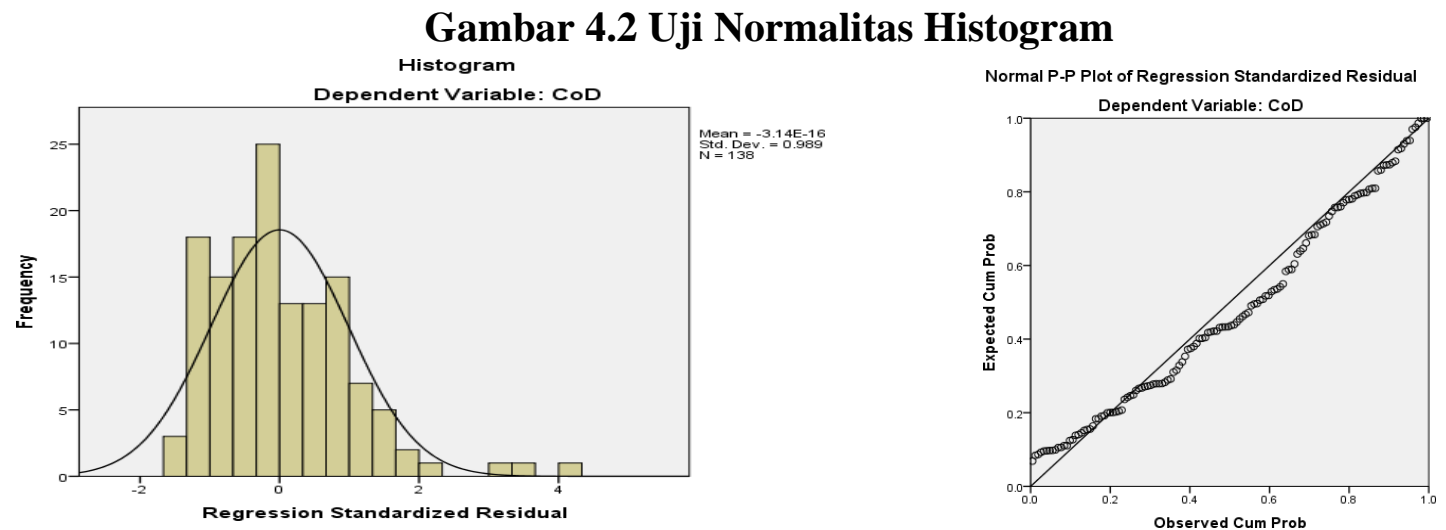

Gambar 4.3 Uji Normalitas Probability Plot

Dari Gambar 4.2. di atas dapat dilihat bahwa grafik histogram menunjukkan pola distribusi normal. Sedangkan pada Gambar 4.3. menunjukkan bahwa grafik normal probability plot menyebar disekitar garis diagonal. Maka, dapat disimpulkan jika model regresi memenuhi asumsi normalitas.

Uji normalitas dengan grafik dapat menyesatkan jika tidak hati-hati, karena bisa saja secara visual kelihatan normal, padahal secara statistik menunjukkan hasil yang sebaliknya. Oleh karena itu, untuk memperkuat uji normalitas dilakukan One-Sample Kolmogorov-Smirnov Test. Hasil dari uji pada Tabel 4.6 berikut.

Tabel 4.6 Hasil Uji Normalitas

\begin{tabular}{|c|c|c|}
\hline \multicolumn{3}{|c|}{ One-Sample Kolmogorov-Smirnov Test } \\
\hline \multicolumn{2}{|c|}{$\mathrm{N}$} & Unstandardized Residual \\
\hline \multirow{3}{*}{ Normal Parameters ${ }^{\mathrm{a}, \mathrm{b}}$} & & 138 \\
\hline \multirow{2}{*}{ Most Extreme Differences } & Mean & .0000000 \\
\cline { 2 - 3 } & Standard Deviation & .02554079 \\
\cline { 2 - 3 } & Absolute & .088 \\
\cline { 2 - 3 } & Positive & .088 \\
\hline
\end{tabular}




\begin{tabular}{|c|c|}
\hline Kolmogorov-Smirnov Z & 1.034 \\
\hline Asymp. Sig. (2-tailed) & .235 \\
\hline
\end{tabular}

Hasil uji normalitas menggunakan One-Sample Kolmogorov-Smirnov Test menunjukkan bahwa Asymp. Sig (2-tailed) 1,034 di atas tingkat signifikansi 5\%. Dengan demikian, dapat disimpulkan bahwa data residual terdistribusi secara normal.

\subsection{Hasil Analisa Linier Berganda}

Dalam penelitian ini, metode analisa yang digunakan adalah analisa regresi linier berganda. Pada dasarnya analisa regresi digunakan untuk memperoleh persamaan regresi dengan cara memasukkan perubahan satu demi satu, sehingga dapat diketahui pengaruh dari setiap variabel.

Pengujian terhadap model penelitian ini untuk mengetahui pengaruh penghindaran pajak yang diukur menggunakan current effective tax rate (ETR) terhadap biaya hutang (COD). Analisa ini diolah dengan menggunakan program SPSS .

Tabel 4.7

Hasil Uji Regresi Linier Berganda ( Tanpa Variabel kontrol)

\begin{tabular}{|c|c|c|c|c|c|c|c|}
\hline \multicolumn{2}{|c|}{ Model } & \multicolumn{2}{|c|}{$\begin{array}{c}\text { Unstandardized } \\
\text { Coefficients }\end{array}$} & $\begin{array}{c}\text { Standardized } \\
\text { Coefficients }\end{array}$ & \multirow{2}{*}{$\mathrm{T}$} & \multirow{2}{*}{ Sig. } & \multirow{2}{*}{ Correlations } \\
\cline { 3 - 9 } \cline { 3 - 8 } & B & Std. Error & Beta & & & Zero-order \\
\hline \multirow{2}{*}{1} & (Constant) & .030 & .004 & & 8.072 & .000 & \\
\cline { 2 - 9 } & Tax_Avoid & .008 & .009 & .076 & .887 & .377 & .076 \\
\hline
\end{tabular}

Berdasarkan tabel diatas diketahui bahwa nilai koefisien dari persamaan regresi dari output didapatkan model persamaan regresi:

$\mathrm{COD}=0.030+0.008$ Tax avoidance $+\mathrm{e}$

Tabel 4.8

Hasil Uji Regresi Linier Berganda ( dengan variabel kontrol)

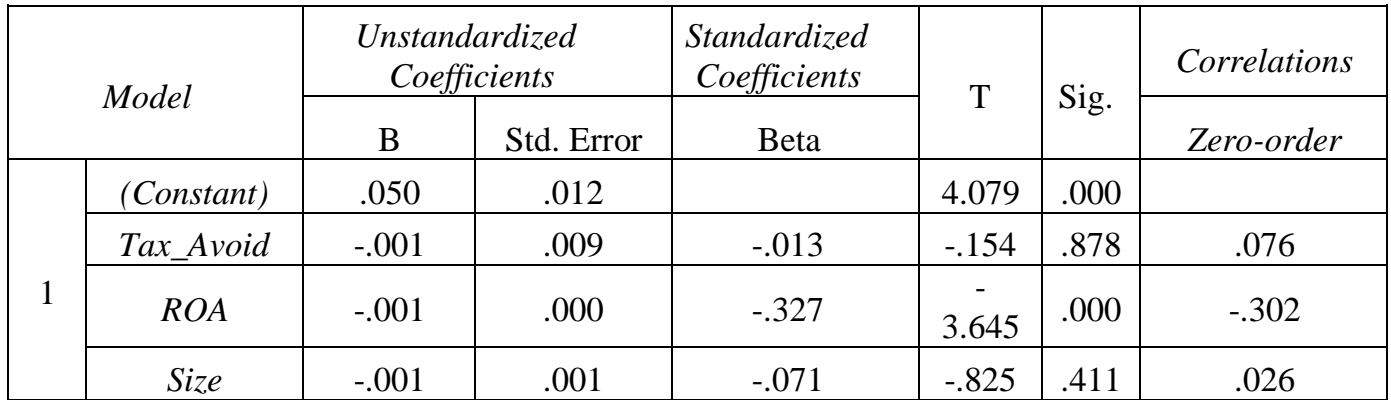

Berdasarkan tabel diatas diketahui bahwa nilai koefisien dari persamaan regresi dari output didapatkan model persamaan regresi:

COD $=0,050-0,001$ TA - 0.001 ROA - 0,001 SIZE +e

Berdasarkan table 4.7 dan 4.8 diatas dapat diketahui:

a. Nilai konstanta sebesar 0,30 manyatakan bahwa apabila variabel tax avoidance bernilai 0 , maka biaya hutang (cost of debt) mengalami peningkatan sebesar 0,30. Dengan adanya variabel kontrol, nilai konstanta sebesar 0,050 menyatakan bahwa apabila tax avoidance, return on asset, dan size bernilai 0 , maka biaya hutang (cost of debt) mengalami peningkatan sebesar 0,050. Dengan catatan variabel lain tetap.

b. Nilai 0,008 menunjukkan bahwa adanya pengaruh positif antara variabel tax avoidance terhadap biaya hutang (cost of debt) sebesar 0,008. Artinya apabila variabel 
tax avoidance naik sebesar 1 satuan maka biaya hutang (cost of debt) akan bertambah sebesar 0,008 . Dengan nilai catatan variabel lain tetap.

c. Dengan adanya variabel kontrol nilai $-0,001$ menunjukkan adanya pengaruh negatif antara tax avoidance, return on asset, dan size terhadap biaya hutang sebesar 0,001. Artinya apabila tax avoidance, return on asset da size naik sebesar 1 satuan maka biaya hutanng (cost of debt) akan berkurang sebesar 0,001 , dengan catatan variabel lain tetap.

\subsection{Koefisien Determinasi $\left(\mathbf{R}^{2}\right)$}

Koefisien determinasi $\left(\mathrm{R}^{2}\right)$ bertujuan untuk mengukur kemampuan model dalam menerangkan variasi variabel dependen. Nilai $\mathrm{R}^{2}$ adalah antara nol dan satu. Nilai yang mendekati nol berarti kemampuan variabel independen dalam menjelaskan variabel dependen sangat terbatas. Nilai yang mendekati satu artinya variabel independen memberikan hampir semua informasi yang dibutuhkan untuk memprediksi variabel dependen.

Table 4.9 Hasil Uji Koefisien Determinasi (Tanpa Variabel Kontrol)

\begin{tabular}{|c|c|c|c|c|c|c|c|}
\hline \multirow[t]{2}{*}{ Model } & \multirow[t]{2}{*}{$\mathrm{R}$} & \multirow{2}{*}{$\begin{array}{c}\mathrm{R} \\
\text { Square }\end{array}$} & \multirow{2}{*}{$\begin{array}{l}\text { Adjusted } \\
\text { R Square }\end{array}$} & \multirow{2}{*}{$\begin{array}{l}\text { Std. Error } \\
\text { of the } \\
\text { Estimate }\end{array}$} & \multicolumn{3}{|c|}{ Change Statistics } \\
\hline & & & & & $\begin{array}{c}\text { R Square } \\
\text { Change }\end{array}$ & $\begin{array}{c}\mathrm{F} \\
\text { Change }\end{array}$ & df1 \\
\hline 1 & $.076^{\mathrm{a}}$ & .006 & -.002 & .02688 & .006 & .787 & 1 \\
\hline
\end{tabular}

Dari tabel 4.9 dapat kita lihat bahwa nilai Adjusted $R$ Square adalah 0,002. Hal tersebut menunjukkan bahwa sebesar $0.2 \%$ biaya hutang (cost of debt) di pengaruhi tax avoidance Sedangkan 99,8\% dipengaruhi oleh model lain diluar penelitian. Nilai Adjusted $R$ Square pada penelitian ini masih sangat kecil, karena masih ada 99,8\% faktor di luar model yang mempengaruhi biaya hutang (cost of debt). Variabel di luar model yang diperkirakan lebih mempengaruhi biaya hutang (cost of debt) yaitu faktor-faktor keuangan lainnya.

Tabel 4.10 Hasil Uji Koefisien Determinasi (dengan variabel kontrol)

\begin{tabular}{|c|c|c|c|c|c|c|c|}
\hline \multirow{2}{*}{ Model } & \multirow{2}{*}{$\mathrm{R}$} & \multirow{2}{*}{ R Square } & $\begin{array}{c}\text { Adjusted } \\
\text { R Square }\end{array}$ & $\begin{array}{c}\text { Standard. Error } \\
\text { of the Estimate }\end{array}$ & \multicolumn{2}{|c|}{ Change Statistics } \\
\cline { 6 - 8 } & & & & & R Square Change & F Change & df1 \\
\hline 1 & $\begin{array}{c}.310 \\
\mathrm{a}\end{array}$ & .096 & .076 & .02583 & .096 & 4.746 & 3 \\
\hline
\end{tabular}

Dari tabel 4.10. dapat kita lihat bahwa nilai Adjusted $R$ Square adalah 0,076. Hal tersebut menunjukkan bahwa sebesar 7,6\% biaya hutang (cost of debt) dipengaruhi oleh tax avoidance, return on asset, dan size. Sedangkan 92,4\% dipengaruhi oleh model lain diluar penelitian.

Nilai Adjusted $R$ Square pada penelitian ini masih sangat kecil, karena masih ada 92,4\% faktor di luar model yang mempengaruhi biaya hutang (cost of debt). Variabel di luar model yang diperkirakan lebih mempengaruhi biaya hutang (cost of debt) yaitu faktor-faktor keuangan lainnya.

\subsection{Uji Signifikansi Simultan ( Uji Statistik F)}

Uji statistik F bertujuan untuk menunjukkan apakah variabel independen secara bersama-sama berpengaruh terhadap variabel dependen. Hasil pengujian statistik F dapat dilihat pada tabel 4.11. berikut:

Tabel 4.11 Uji Statistik F

\begin{tabular}{|c|c|c|c|c|c|c|c|}
\hline \multicolumn{2}{|c|}{ Model } & Sum of Squares & Df & Mean Square & & F & Sig. \\
\hline \multirow{4}{*}{1} & Regression & .009 & 3 & .003 & & 4.746 & $.004^{\mathrm{b}}$ \\
\cline { 2 - 8 } & Residual & .089 & 134 & .001 & & & \\
\cline { 2 - 8 } & Total & .099 & 137 & & & & \\
\hline
\end{tabular}

Dari tabel di atas dapat dilihat bahwa pengujian simultan ini menghasilkan nilai F hitung 4,746

Vol : 8, No : 2, 2020

Jurnal Akuntansi dan Perpajakan Indonesia UNIMED

68 
dan nilai dari signifikansinya 0,004 . Nilai $\mathrm{F}$ tabel dari model ini adalah 2.67. Hasil tersebut menunjukkan bahwa variable tax avoidance, return on asset, dan size secara simultan berpengaruh signifikan terhadap biaya hutang (cots of debt), dapat dibuktikan dengan nilai $\mathrm{F}$ hitung yang lebih besar dari F tabel dan juga nilai signifikansinya yang lebih kecil dari 0.05 .

\subsection{Uji Parameter Individual ( Uji Statistik T)}

Uji statistik t menunjukkan seberapa jauh pengaruh masing-masing variabel independen terhadap variabel dependen. Hasil dari uji statistik t dapat dilihat pada tabel 4.12 dan 4.13. berikut:

Table 4.12 Hasil Uji statistik T (tanpa Variabel kontrol)

\begin{tabular}{|c|c|c|c|c|c|c|c|}
\hline \multicolumn{2}{|c|}{ Model } & \multicolumn{2}{|c|}{$\begin{array}{c}\text { Unstandardized } \\
\text { Coefficients }\end{array}$} & $\begin{array}{c}\text { Standardized } \\
\text { Coefficients }\end{array}$ & \multirow{2}{*}{$\mathrm{T}$} & \multirow{2}{*}{ Sig. } & \multirow{2}{*}{ Correlations } \\
\cline { 3 - 9 } \multicolumn{2}{|c|}{} & B & Std. Error & Beta & & & Zero-order \\
\hline \multirow{3}{*}{1} & (Constant) & .030 & .004 & & 8.072 & .000 & \\
\cline { 2 - 9 } & Tax_Avoid & .008 & .009 & .076 & .887 & .377 & .076 \\
\hline
\end{tabular}

Dari tabel di atas, kita dapat menguji hipotesis yang ada dalam penelitian ini dan dijelaskan sebagai berikut: Ha1: tax avoidance berpengaruh positif terhadap biaya hutang (cots of debt)

Berdasarkan tabel di atas, dapat dilihat bahwa tingkat signifikansi dari tax avoidance adalah 0,377 lebih besar dari 0.05, sehingga tax avoidance tidak berpengaruh signifikan terhadap biaya hutang (cost of debt). Nilai t-hitung tax avoidance sebesar 0,887, dan t-tabel sebesar 2,672 (nilai absolut). Karena nilai t-hitung lebih kecil dari t-tabel, maka Ho diterima Hal ditolak. Dari hasil tersebut dapat disimpulkan bahwa tax avoidance tidak berpengaruh terhadap biaya hutang (cost of $d e b t$ ), hasil ini tidak sesuai dengan hipotesis dalam penelitian.

Table 4.13 Hasil Uji statistik T (Dengan Variabel Kontrol)

\begin{tabular}{|c|c|c|c|c|c|c|c|}
\hline \multicolumn{2}{|c}{ Model } & \multicolumn{2}{|c|}{$\begin{array}{c}\text { Unstandardized } \\
\text { Coefficients }\end{array}$} & $\begin{array}{c}\text { Standardized } \\
\text { Coefficients }\end{array}$ & \multirow{2}{*}{$\mathrm{T}$} & \multirow{2}{*}{ Sig. } & correlations \\
\cline { 2 - 8 } \multicolumn{2}{c|}{} & B & Std. Error & Beta & & & zero-order \\
\hline \multirow{4}{*}{1} & (Constant) & .050 & .012 & & 4.079 & .000 & \\
\cline { 2 - 8 } & Tax_Avoid & -.001 & .009 & -.013 & -.154 & .878 & .076 \\
\cline { 2 - 8 } & ROA & -.001 & .000 & -.327 & -3.645 & .000 & -.302 \\
\cline { 2 - 8 } & Size & -.001 & .001 & -.071 & -.825 & .411 & .026 \\
\hline
\end{tabular}

Dari tabel di atas, kita dapat menguji hipotesis yang ada dalam penelitian ini dan dijelaskan sebagai berikut: Ha1: tax avoidance berpengaruh positif terhadap biaya hutang (cots of debt)

Berdasarkan tabel di atas, dapat dilihat bahwa tingkat signifikansi dari tax avoidance adalah 0,878, dan ukuran perusahaan (size) adalah 0,411 lebih besar dari 0.05, sehingga tax avoidance dan size tidak berpengaruh signifikan terhadap biaya hutang (cost of debt). Nilai t- hitung tax avoidance sebesar -0.154, size -0,825 dan t-tabel sebesar 2,672 (nilai absolut). Karena nilai t-hitung lebih kecil dari t-tabel, maka Ho diterima Hal ditolak. Dari hasil tersebut dapat disimpulkan bahwa tax avoidance tidak berpengaruh terhadap biaya hutang (cost of debt), hasil ini tidak sesuai dengan hipotesis dalam penelitian.

Dan dapat dilihat bahwa tingkat signifikansi dari return on asset adalah 0.000 lebih kecil dari 0,05 , sehingga return on asset berpengaruh terhadap biaya hutang (cots of debt). Nilai t-hitung sebesar -3.645 dan t-table sebesar 2,672.

\subsection{Pembahasan Hipotesis}

Pembahasan hipotesis ini adalah penjelasan yang lebih terperinci tentang hipotesis dalam penelitian baik secara simultan maupun parsial. Berdasarkan analisis hasil uji f, bahwa secara simultan tax avoidance, size, dan return on asset berpengaruh dan signifikan terhadap biaya hutang. Dan hasil analisis dari uji statistik t dapat diketahui bahwa tax avoidance tidak berpengaruh terhadap biaya hutang (cost of debt), Hal tidak terbukti. Hasil uji ini tidak sesuai dengan penelitian yang dilakukan oleh Indah Massri (2012), dan Sri Amanda (2017), yang menyatakan bahwa tax avoidance 
berpengaruh positif dan signifikan terhadap biaya hutang (cost of debt), dimana jika nilai tax avoidance tinggi, maka jumlah biaya hutang (cost of debt) juga meningkat.

Penelitian ini sesuai dengan penelitian Utkir Kholbadalov MSc (2012) dan Heni Kurniawan dan Janice Ekasanti Santosa (2016), bahwa tax avoidance berhubungan negatif terhadap biaya hutang. Dengan kata lain perusahaan yang melakukan penghindaraan pajak pada saat ini tidak selalu memiliki hutang yang banyak. Dalam penelitian ini dapat diketahui bahwa tax avoidance tidak dapat mempengaruhi cost of debt secra tersendiri, tax avoidance berpengaruh ketika size dan return on asset sebaagai variabel kontrol yang memperkuat pengaruh tax avoidance terhadap cots of debt. Periode penelitian ini juga dilakukan setelah pemerintah melakukan reformasi perpajakan dan juga dengan adanya Peraturan Menteri Keuangan No.169/PMK.010/2015 mengenai besaran perbandingan hutang dan modal perusahaan yang telah dikeluarkan pada tahun 2015 yang membuat perusahaan pada saat ini berhati-hati di dalam mengelola hutang.

Hal lain yang perlu diperhatikan dari penelitian ini dimana return on asset mempunyai pengaruh negatif dan signifikan terhadap biaya hutang (cost of debt). Dimana dengan adanya tax avoidance akan cenderung mengurangi profitabilitas perusahaan. Hal ini mendukung trade of theory yang mengungkapkan adanya manfaat pajak atas penggunaan hutang, sehingga biaya hutang yang di tanggung perusahaan akan cenderung mengurangi profitabilitas untuk melakukan penghematan pajak.

\section{Kesimpulan Dan Saran}

\subsection{Kesimpulan}

Berdasarkan hasil analisa data dan pembahasan mengenai pengaruh tax avoidance terhadap cost of debt dengan variabel kontrol return on asset dan size yang telah diuraikan pada bab sebelumnya, maka kesimpulan yang dapat ditarik dari penelitian ini sebagai berikut :

1. Bahwa secara simultan tax avoidance, size, dan return on asset berpengaruh dan signifikan terhadap biaya hutang, Pada perusahaan manufaktur yang terdaftar di Bursa Efek Indonesia periode 2015 - 2017. Hasil ini di buktikan dengan nilai $\mathrm{F}$ hitung sebesar 4,746 dan tingkat signifikansinya sebesar 0,004 .

2. Bahwa tax avoidance tidak berpengaruh terhadap cost of debt. Pada perusahaan manufaktur yang terdaftar di Bursa Efek Indonesia periode 2015 - 2017 Hasil ini dibuktikan dengan nilai t-hitung tax avoidance sebesar 0,887 dan tingkat signifikansi sebesar 0,377 lebih besar dari 0.05. Dan dengan variabel kontrol tax avoidance tidak berpengaruh terhadap cost of debt pada perusahaan manufaktur yang terdaftar di Bursa Efek Indonesia periode 2015 - 2017. Hasil ini dibuktikan dengan nilai t-hitung sebesar -0,154 dan tingkat signifikansi 0,878 lebih besar dari 0,05.

3. Variabel kontrol size tidak berpengaruh terhadap cost of debt pada perusahaan manufaktur yang terdaftar di Bursa Efek Indonesia periode 2015 - 2017, yang dibuktikan dengan nilai t- hitung 0,825 dan tingkat signifikansi 0,411 lebih besar dari 0,05.

4. Variabel kontrol return on asset berpengaruh negatif dan signifikan terhadap cost of debt pada perusahaan manufaktur yang terdaftar di Bursa Efek Indonesia periode 2015 - 2017, dibuktikan dengan nilai t-hitung sebesar -3,645 dan tingkat signifikansi 0,000 lebih kecil dari 0,05.

\subsection{Saran}

Berdasarkan pembahasan dan kesimpulan yang diperoleh dalam penelitian ini, maka

saran yang dapat diberikan peneliti adalah sebagai berikut:

1. Penelitian selanjutnya diharapkan dapat mempertimbangkan penggunaan data yang dikumpulkan dengan teknik analisa data sehingga diperoleh informasi mengenai liabilitas jangka panjang dan jangka pendek yang berbunga terpisah dari yang tidak berbunga dan cost of debt dapat diukur secara lebih tepat. Sehingga pengukuran nilai cost of debt yang akurat sehingga tidak menimbulkan hasil yang bias.

2. Penelitian selanjutnya diharapkan juga menggunakan data industri yang homogen / sejenis sehingga data yang dikumpulkan dengan teknik analisa data dapat diukur secara lebih tepat dan tidak menimbulkan hasil yang bias. 
3. Pihak internal supaya lebih bijak dalam mengambil keputusan dalam melakukan perencanaan pajak yaitu tax avoidance sehingga kebijakan perusahaan tidak menimbulkan resiko yang tinggi yang dapat mengakibatkan asimetri antara pihak internal dengan pihak eksternal.

\section{DAFTAR PUSTAKA}

Brown, Karen B. (2012). A Comparative Look at Regulation of Corporate Tax Avoidance. New York: Springer.

Chhairil Anwar. 2013. Manajemen perpajakan strategi perencanaan pajak dan bisnis. jakarta: PT Gramedia Pustaka Utama.

Ekasanti, Janice dan Heni Kurniawan. 2014. Analisis Pengaruh Tax Avoidance Terhadap Cost Of Debt Pada Perusahaan Manufaktur Yang Terdaftar di Bursa Efek Indonesia Selama Periode 2010-2014. Publised Skripsi. Universitas Atma Jaya Yogyakarta. Yogyakarta.

Fitriani, Sri Amanda. 2017. Pengaruh Tax Avoidance Terhadap Biaya Hutang Pada Perusahaan Manufaktur Yang Terdaftar Di Bursa efek Indonesia. Skripsi. Universitas Sumatera Utara. Medan.

Ghozali, I. (2013) Aplikasi Analisis Multivariate dengan Program IBM SPSS 21. 7th edn. Semarang: UNDIP.

Hartono, Jogiyanto. 1998. Teori Portofolio dan Analisis Investasi. Yogyakarta: BPFE.

Ika Ernawati. 2014. Analisis pengaruh tax avoidance terhadap biaya hutang dan pemilikan instutisional pada perusahaan manufaktur yang terdaftar dibursa efek Indonesia. Naskah publikas. Universitas Muhammadiah Surakarta. Surakarta.

Kholbadalov, U. 2012. The Relationship of Corporate Tax Avoidance, Cost of Debt and Institutional Ownership: Evidence from Malaysia, Atlantic Review of Economics, 2.

Lim, YD. (2011). Tax avoidance, cost of debt and shareholder activism: Evidence from Korea. Journal of Banking \& Finance 35, 456-470.

Marcelliana, Elsa . 2014. Pengaruh Tax Avoidance Terhadap Cost Of Debt Pada Perusahaan ManufakturYang Terdaftar Di Bursa Efek IndonesiaPeriode 2010-2012. Universitas Atma Jaya Yogyakarta. Yogyakarta.

Masri, Indah dan Dwi Martani. 2012. Tax Avoidance terhadap Cost of Debt. Simposium Nasional Akuntansi XV. Universitas Indonesia. Depok.

Modigliani dan Miller. 1963. Corporate Income Taxes on the Cost of Capital. American Economic Review 53. Amerika.

Myers dan Marcus. 2001. Fundamentals of corporste finance. Edisi 3. McGraw-Hill. New York.

Novianti, Arti Resha. 2014. Pengaruh Penghindaran Pajak Terhadap Biaya Hutang. Publised Skripsi. Universitas Pendidikan Indonesia. Bandung.I

Nugrahadi, E. W., Maipita, I., \& Situmeang, C. (2020). Dominant Socio-Economic Indicators on the Growth of Small-Scale Industrial Sector: Empirical Evidence with Principal Component Analysis. Revista Espacios, 41 (2).

Pittman, J., Fortin, S., (2004).Auditor choice and the cost of debt capital for newly public firms.Journal of Accounting and Economics 37, 113-136.

Sari, D.K. (2010). Ownership Characteristics, Corporate Govermance, and Tax Aggressiveness: IFRS Convergence and application Faculty of Economics Universitas Indonesia BaliIndonesia, 27-28 Oktober 2010.

Sihombing, T. P., Nasirwan \& Situmeang, C. (2020). The Effect of Accounting Information and Organizational Culture on Decision Making. Budapest International Research and Critics Institute (BIRCI-Journal): Humanities and Social Sciences, 3 (1). 522-530.

Situmeang, C., \& Hutabarat, E. (2017). Analisis Pengaruh Non Financial Measures Disclosure, Corporate Governance Dan Kualitas Audit Terhadap Performance Melalui Cost Of Equity Perusahaan. Jurnal Akuntansi, Keuangan, \& Perpajakan, 5 (2). 1-16.

Suandy, Erly. 2011. Hukum Pajak. Jakarta: Salemba Empat.

Utama, Fahreza., Kirana, Dwi Jaya., Sitanggang, Kornel. 2019. Pengaruh Penghindaran Pajak Terhadap Biaya Hutang Dan Kepemilikan Institusional Sebagai Pemodrenisasi. Jurnal Bisnis dan Akuntansi, 21(1), 47-60.

Warsono. 2003. Manajemen Keuangan Perusahaan. Jilid 1. Bayu Media Publishing. Malang. 